\title{
Pengaruh Dosis NPK Mutiara dan Konsentrasi Air Laut terhadap Pertumbuhan dan Hasil Kacang Tanah (Arachis
}

\author{
hipogeae L.) Varietas Kijang \\ Effect of NPK Pearl Dose and Seawater Concentration on Growth and \\ Yield of Peanut (Arachis hipogeae L.) Kijang Varieties
}

\author{
Engkus Kusnaedin ${ }^{1}$, Atak Tauhid ${ }^{2}$, dan Jajang Supriatna ${ }^{2}$ \\ ${ }^{1}$ Program Studi Agroteknologi, Fakultas Pertanian, Universitas Garut, \\ Jl. Raya Samarang No.52A, Tarogong Kaler, Kabupaten Garut, Jawa Barat 44151 \\ e-mail : ataktauhid@uniga.ac.id
}

\begin{abstract}
ABSTRAK
Kacang tanah (Arachis hypogaea L.) merupakan salah satu komoditas pangan yang memiliki nilai ekonomi tinggi dan merupakan sumber pangan yang memiliki gizi cukup. Penelitian ini bertujuan untuk mengetahui pengaruh dosis NPK mutiara dan konsentrasi air laut terhadap pertumbuhan dan hasil kacang tanah. Percobaan dilakukan di Desa Pasawahan, Kecamatan Tarogong Kaler, Kabupaten Garut dari bulan April hingga Juli 2019. Desain yang digunakan dalam penelitian ini adalah Rancangan Acak Kelompok (RBD) pola faktorial $4 \mathrm{x}$ 4 dengan dua ulangan, faktor pertama adalah mutiara NPK dosis $(\mathrm{P})$ terdiri dari empat tingkatan: $\mathrm{p} 0=0 \mathrm{~g} /$ Polybag, $\mathrm{p} 1=1,2 \mathrm{~g} /$ Polybag, $\mathrm{p} 2=1,8 \mathrm{~g} /$ Polybag, dan p3 = 2,4 g / Polybag. Konsentrasi faktor kedua Air Laut (A), terdiri dari empat tingkatan: $\mathrm{a} 0=0 \mathrm{ml} /$ liter, $\mathrm{a} 1=30 \mathrm{ml} /$ liter, $\mathrm{a} 2=40 \mathrm{ml} /$ liter, dan a3 = $50 \mathrm{ml} /$ liter. Hasil penelitian menunjukkan bahwa tidak ada interaksi antara berbagai dosis NPK dan konsentrasi air laut pada pertumbuhan dan hasil kacang. Secara independen, dosis 1,2 g / polybag NPK efektif dan efesien untuk menunjukkan pengaruh terbaik pada semua parameter pengamatan terhadap pertumbuhan tanaman kacang tanah, sedangkan berbagai konsentrasi air laut tidak menunjukkan hasil yang signifikan pada semua parameter pengamatan.
\end{abstract}

Kata kunci: Kacang Tanah, NPK Mutiara, Konsentrasi Air Laut.

\section{ABSTRACT}

Peanuts (Arachis hypogaea L.) is one of the food commodities that has high economic value and is a food source that has sufficient nutrition. One of the methods that need to be considered to increase the production of peanut plants, so what needs to be questioned is as the main support of plant growth in the planting media. This study aims to determine the effect of NPK doses of pearls and concentration of seawater on the growth and yield of peanuts. The experiment was carried out in Pasawahan Village, Tarogong Kaler Subdistrict, Garut Regency from April to July 2019. The design used in the study was a randomized block design (RBD) $4 \times 4$ factorial pattern with two replications, the first factor 
was NPK pearl dose $(P)$ consists of four levels: $p 0=0 \mathrm{~g} /$ Polybag, $p 1=1.2 \mathrm{~g} /$ Polybag, p2 = $1.8 \mathrm{~g} /$ Polybag, and $\mathrm{p} 3=2.4 \mathrm{~g} /$ Polybag. The second factor concentration of Sea Water (A), consists of four levels: $a 0=0 \mathrm{ml}$ liter, a1 $=30$ $\mathrm{ml} /$ liter, a2 $=40 \mathrm{ml} /$ liter, and a3 $=50 \mathrm{ml} /$ liter. The results showed that there were no interactions between various NPK doses and sea water concentrations on peanut growth and yield. Independently the $1,2 \mathrm{~g} /$ polybag NPK dose was efective and efesien to show the best influence on all observational parameters on the growth of peanut plants, while various concentrations of seawater did not show significant results on all observational parameters.

Keywords : Peanut, NPK Mutiara, Sea Water Concentration.

\section{PENDAHULUAN}

Kacang tanah (Arachis hypogaea L.) merupakan salah satu komoditas pangan yang bernilai ekonomi tinggi dan merupakan sumber pangan yang memiliki nutrisi yang cukup lengkap. Kacang tanah kaya kandungan lemak, protein yang tinggi, zat besi, vitamin E,vitamin B kompleks, fosfor, vitamin A, vitamin K, lesitin, kolin dan kalsium. Kandungan protein biji kacang tanah merupakan parameter yang menentukan kualitas nutrisi biji dan berkorelasi negatif dengan kandungan minyak biji dan persentase oleat. Biji kacang tanah mengandung $40 \%$ sampai $48 \%$ minyak, $25 \%$ protein, dan $18 \%$ karbohidrat dan vitamin B kompleks (Kumar dkk 2014).

Kacang tanah termasuk suku (family) Papiolionaceae dan genus Arachisyang berasal dari benua Amerika (Brazilia). Kacang tanah merupakan tanaman leguminosa yang cukup penting di Indonesia.Tanaman ini merupakan tanaman yang paling banyak ditanam setelah padi, jagung, dan kacang kedelai. Tanaman kacang tanah mempunyai banyak nama daerah seperti kacang una, kacang jebrol, kacang bandung, kacang koli, kacang tuban, dan kacang bangkala (Poespadarsono, 1988).

Produktivitas kacang tanah di Indonesia masih rendah. Menurut Badan Pusat Statistik produksi kacang tanah tahun 2015 sebanyak 605,45 ribu ton biji kering, mengalami penurunan sebanyak 33,45 ribu ton $(5,24 \%)$ dibandingkan tahun 2014. Penurunan produksi kacang tanah terjadi di luar Pulau Jawa yaitu sebanyak 44,51 ribu ton, sementara di Pulau Jawa terjadi peningkatan produksi sebanyak 11,07 ributon. Penurunan produksi terjadi karena penurunan luas panen 
seluas 44,99 ribu hektar $(9,01 \%)$ sedangkan produktivitas mengalami kenaikan sebesar 0,54 kuintal/hektar (4,22\%) (BPS, 2019).

Tingkat kebutuhan dan pemanfaatan semacam ini, maka kacang tanah dituntut untuk lebih dikembangkan dan ditingkatkan produktivitasnya. Pengembangan dan peningkatan produksi komoditas kacang tanah ini tidak lain karena tingkat produktivitas kacang tanah di Indonesia masih kalah dengan produksi kacang tanah di negara lain. Angka produksi kacang tanah di Indonesia, di antara jenis-jenis kacang-kacangan lainnya, masih menempati urutan kedua setelah kedelai (BPS, 2019). Walaupun angka produksi kacang tanah telah menempati urutan kedua, namun belum dapat memenuhi kebutuhan produksi Nasional, sehingga untuk Indonesia tingkat produktivitas hasil produksi komoditi kacang tanah dinilai masih rendah.

Salah satu cara yang perlu diperhatikan untuk meningkatan produksi tanaman kacang tanah, maka yang perlu adalah ketersediaan unsur hara sebagai penopang utama pertumbuhan tanaman pada media tanamnya. Bahan organik dan anorganik mutlak diperlukan tanaman untuk tumbuh, berkembang dan berproduksi.

Pemupukan dapat menjadi salah satu upaya yang dapat ditempuh dalam memaksimalkan hasil tanaman. Pemupukan dapat dilakukan sebagai upaya untuk mencukupi kebutuhan tanaman agar tujuan produksi dapat dicapai. Namun apabila penggunaan pupuk yang tidak bijaksana atau berlebihan dapat menimbulkan masalah bagi tanaman yang diusahakan, seperti keracunan, kualitas produksi rendah dan selain itu pula biaya produksi tinggi dan dapat menimbulkan pencemaran

Usaha yang dapat dilakukan untuk meningkatkan produktivitas tanaman adalah dengan pemberian pupuk baik organik maupun anorganik. Pemberian pupuk bertujuan untuk meningkatkan ketersediaan unsur hara dalam tanah. Salah satu jenis pupuk majemuk yang dapat digunakan untuk meningkatkan produktivitas tanaman kacang tanah adalah pupuk NPK mutiara (16:16:16). Hal ini dilakukan karena pupuk yang mengandung unsur nitrogen, fosfor dan kalium merupakan kunci utama dalam usaha budidaya tanaman, bila ketiga unsur hara ini tidak tersedia atau tersedia terlalu lambat, atau berada tidak dalam keseimbangan 
maka perkembangan tanaman akan terhambat (Sarwono, 1995).

Pupuk NPK mutiara (16:16:16) merupakan salah satu pupuk anorganik bersifat majemuk yang memiliki unsur hara makro $\mathrm{N}$, $\mathrm{P}$, dan $\mathrm{K}$ masing-masing 16\% (Fahmi, 2014). Pupuk NPK mutiara ini cocok digunakan pada semua jenis tanaman buah, bunga, sayuran, tanaman pangan dan palawija.

Penurunan produktivitas tanaman juga selain kekurangan unsur hara faktor kekurangan air pun dapat menjadi kendala dalam proses budidaya tanaman kacang. Salah satu cara untuk mengatasinya adalah menggunakan air laut. Secara alami kebutuhan air untuk tanaman dapat dipenuhi dari air hujan. Kenyataannya di beberapa tempat dan dalam waktu-waktu tertentu jumlah air hujan tidak mencukupi untuk memenuhi kebutuhan air bagi tanaman. Sedangkan infrastruktur, sarana prasarana irigasi masih merupakan permasalahan mendasar sektor pertanian. Kondisi ini menyebabkan pertumbuhan tanaman menjadi tidak optimal yang selanjutnya dapat mengganggu tingkat produktivitasnya.

Air laut mengandung banyak ion mengakibatkan tingginya salinitas. Distribusi hara di dalam air laut dipengaruhi oleh sirkulasi air laut, proses biologi dan mineralisasi serta regenerasi nutrisi dengan adanya migrasi hewan dan suplai dari daratan. Rata-rata konsentrasi garam-garam terlarut di air laut berkisar 3.5\%, namun konsentrasi tersebut tergantung pada lokasi dan laju evaporasi. Konsentrasi ion utama terlarut bervariasi dari satu lokasi ke lokasi lain, namun secara proporsi relatifnya konstan. Air laut sudah banyak digunakan untuk mengairi tanaman yang toleran terhadap salinitas pada daerah- daerah dekat pantai (Pichard dan Emery, 1990).

Konsentrasi garam pada tanah lebih tinggi dibandingkan dalam sel-sel akar (plasmolisis), akan menyebabkan tanah menyerap air dari akar dan tanaman sehingga tanaman akan layu dan mati. Pengaruh yang merusak dari garam pada tanah itu tidak hanya disebabkan oleh daya osmosis tetapi juga oleh sodium $\left(\mathrm{Na}^{+}\right)$ dan klor ( $\left.\mathrm{CI}^{-}\right)$akan menyebabkan keracunan pada tanaman (Fitter dan Hay, 1991). Berdasarkan pemikiran tersebut perlu dilakukan metode aplikasi pupuk NPK Mutiara dan berbagai konsentrasi air laut pada budidaya kacang tanah. Diharapkan metode aplikasi tersebut dapat meningkatkan produksi pada tanaman kacang tanah. 


\section{METODE PENELITIAN}

Metode yang digunakan adalah metode eksperimen dengan menggunakan Rancangan Acak Kelompok (RAK) pola faktorial 4 x 4 dengan dua ulangan. Faktor pertama merupakan dosis pupuk NPK $(\mathrm{P})$, terdiri atas empat taraf: $\mathrm{p}_{0}=0$ gr/ Polybag, $\mathrm{p}_{1}=1,2 \mathrm{gr} /$ Polybag, $\mathrm{p}_{2}=1,8 \mathrm{gr} /$ Polybag, $\mathrm{p}_{3}=2,4 \mathrm{gr} /$ Polybag. Faktor kedua konsentrasi Air Laut (A), terdiri atas empat taraf : $\mathrm{a}_{0}=0 \mathrm{ml} /$ liter, $\mathrm{a}_{1}$ $=30 \mathrm{ml} /$ liter, $\mathrm{a}_{2}=40 \mathrm{ml} /$ liter, $\mathrm{a}_{3}=50 \mathrm{ml} / \mathrm{liter}$. Analisis data dari hasil pengamatan dilakukan berdasarkan model linier Rancangan Acak Kelompok (RAK) menurut Warsa dan Achyar (1982), yaitu dengan menggunakan rumus:

$$
\mathrm{X}_{i j k}=\mu+\mathrm{r}_{\mathrm{i}}+\mathrm{P}_{\mathrm{j}}+\mathrm{G}_{\mathrm{k}}+(\mathrm{PG})_{j k}+\mathrm{C}_{i j k}
$$

Kaidah pengambilan keputusan menggunakan uji F, jika terjadi perbedaan yang nyata antar perlakuan maka data dianalisis lanjut menggunakan uji jarak berganda duncan taraf $5 \%$.

\section{HASIL DAN PEMBAHASAN}

Rata-rata tinggi tanaman dapat dilihat dalam Tabel 1. Hasil analisis ragam menunjukkan tidak terjadi interaksi antara dosis pupuk NPK dan konsentrasi air laut terhadap rata-rata tinggi tanaman pada tanaman kacang tanah, akan tetapi secara mandiri perlakuan dosis NPK pada umur 30, 45, dan 60 HST menunjukkan bahwa perlakuan $\mathrm{p}_{0}(0 \mathrm{gr} /$ polybag $)$ berbeda nyata dengan taraf perlakuan $\mathrm{p}_{1}(1,2$ gr/polybag), $\mathrm{p}_{2}$ (1,8 gr/polybag), dan $\mathrm{p}_{3}$ (2,4 gr/polybag), sedangkan perlakuan $\mathrm{p}_{1}$ tidak berbeda nyata dengan perlakuan $\mathrm{p}_{2}$ dan $\mathrm{p}_{3}$.

Hasil yang berbeda diduga akibat dari pemberian NPK yang mampu meningkatkan kekurangan hara pada tanah. Hasil analisis tanah yang terdapat pada Lampiran 2 menunjukkan adanya kekurangan unsur nitrogen dan kalium pada kondisi sedang. Akibat hal tersebut pada perlakuan kontrol yang tidak diberi perlakuan NPK menjadi lebih lambat pertumbuhannya. Berbeda dengan tanaman yang diberi aplikasi tambahan pupuk.

Menurut Imran (2005) pupuk NPK mengandung tiga senyawa penting antara lain ammonium nitrat $\left(\mathrm{NH}_{4} \mathrm{NO}_{3}\right)$, amonium dihidrogen fosfat $\left(\mathrm{NH}_{4} \mathrm{H}_{2} \mathrm{PO}_{4}\right)$, dan kalium klorida (KCl). Menurut Novizan (2007), pupuk NPK Mutiara (16:16:16) adalah pupuk majemuk yang memiliki komposisi unsur hara yang 
seimbang dan dapat larut secara perlahan-lahan. Pupuk NPK Mutiara berbentuk padat, memiliki warna kebiru- biruan dengan butiran mengkilap seperti mutiara. Pupuk NPK Mutiara memiliki beberapa keunggulan antara lain sifatnya yang lambat larut sehingga dapat mengurangi kehilangan unsur hara akibat pencucian, penguapan, dan penjerapan oleh koloid tanah. Selain itu, pupuk NPK mutiara memiliki kandungan hara yang seimbang, lebih efisien dalam pengaplikasian, dan sifatnya tidak terlalu higroskopis sehingga tahan simpan dan tidak mudah menggumpal.

Tabel 1. Rata-rata Tinggi Tanaman $(\mathrm{cm})$

\begin{tabular}{lrrc}
\hline Tinggi Tanaman $(\mathrm{cm})$ & Umur 30 HST & Umur 45 HST & Umur 60 HST \\
\hline Dosis NPK & $9,49 \mathrm{a}$ & $16,11 \mathrm{a}$ & $16,70 \mathrm{a}$ \\
$\mathrm{p}_{0}$ & $12,01 \mathrm{~b}$ & $19,28 \mathrm{~b}$ & $19,38 \mathrm{~b}$ \\
$\mathrm{p}_{1}$ & $10,96 \mathrm{~b}$ & $18,80 \mathrm{~b}$ & $19,44 \mathrm{~b}$ \\
$\mathrm{p}_{2}$ & $11,66 \mathrm{~b}$ & $19,18 \mathrm{~b}$ & $20,68 \mathrm{~b}$ \\
$\mathrm{p}_{3}$ & & \\
Konsentrasi Air Laut & $11,26 \mathrm{a}$ & $17,33 \mathrm{a}$ & $18,65 \mathrm{a}$ \\
$\mathrm{a}_{0}$ & $10,41 \mathrm{a}$ & $18,70 \mathrm{a}$ & $19,13 \mathrm{a}$ \\
$\mathrm{a} 1$ & $11,51 \mathrm{a}$ & $19,06 \mathrm{a}$ & $19,39 \mathrm{a}$ \\
$\mathrm{a}_{2}$ & $10,94 \mathrm{a}$ & $18,28 \mathrm{a}$ & $19,03 \mathrm{a}$ \\
$\mathrm{a}_{3}$ & &
\end{tabular}

Keterangan : Angka rata-rata pada setiap kolom yang ditandai dengan huruf yang sama menunjukkan tidak berbeda nyata menurut Uji Jarak Berganda Duncan padataraf 5\%.

Perlakuan konsentrasi air laut menunjukkan tidak ada pengaruh nyata antara perlakuan. Hal ini diduga pemberian air garam yang dilakukan sangat sedikit sehingga tidak berefek pada tanaman. Kandungan natrium yang terdapat pada air laut yang mampu menjadi pengganti kalium kurang berperan karena jumlah yang sedikit dan kandungan kalium pada tanah telah berada pada kondisi sedang.

Menurut Milero (1996) Rata-rata konsentrasi garam-garam terlarut di air laut berkisar 3,5\%, namun konsentrasi tersebut tergantung pada lokasi dan laju evaporasi. Menurut Brown et., al, (1989) kandungan natrium pada air laut adalah sebesar 10,556 ppm jumlah yang sangat sedikit tersebut pada penelitian di encerkan dengan air bersih sehingga semakin menurunkan

jumlah kandungan hara pada air laut. Oleh karena itu terlihat tidak 
memberikan dampak yang berbeda nyata dengan kontrol.

Hasil analisis ragam menunjukkan tidak terjadi interaksi antara dosis pupuk NPK dan konsentrasi air laut terhadap rata- rata luas daun pada tanaman kacang tanah, pengaruh mandiri dosis pupuk NPK menunjukkan hasil yang berbeda nyata pada perlakuan $\mathrm{p}_{0}$ dibandingkan $\mathrm{p}_{1}, \mathrm{p}_{2}$, dan $\mathrm{p}_{3}$, tetapi perlakuan $\mathrm{p}_{1}$ tidak berbeda nyata dengan perlakuan $\mathrm{p}_{2}$ dan $\mathrm{p}_{3}$. Rata- rata luas daun dapat dilihat pada Tabel 2 . Tabel 2. Rata-rata Luas Daun $\left(\mathrm{cm}^{2}\right)$

\begin{tabular}{lc}
\hline \multicolumn{1}{c}{ Perlakuan } & Luas Daun $\left(\mathrm{cm}^{2}\right)$ \\
\hline Dosis NPK (P) & \\
$\mathrm{p}_{0}$ & $0,23 \mathrm{a}$ \\
$\mathrm{p}_{1}$ & $0,67 \mathrm{~b}$ \\
$\mathrm{p}_{2}$ & $0,69 \mathrm{~b}$ \\
$\mathrm{p}_{3}$ & $0,78 \mathrm{~b}$ \\
\hline
\end{tabular}

Konsentrasi Air Laut

$\mathrm{a}_{0}$

$\mathrm{a}_{1} \quad 0,71 \mathrm{a}$

$\mathrm{a}_{2} \quad 0,40 \mathrm{a}$

$\mathrm{a}_{3} \quad 0,80 \mathrm{a}$

$\frac{0,45 \text { a }}{\text { Keterangan : Angka rata-rata pada setiap kolom yang ditandai dengan huruf yang }}$ sama menunjukkan tidak berbeda nyata menurut Uji Jarak Berganda Duncan pada taraf 5\%.

Hasil analisis ragam menunjukkan hasil yang berbeda nyata antara taraf perlakuan kontrol dengan perlakuan NPK. Hal ini diduga karena kandungan nitrogen yang terdapat pada pupuk NPK. Pada lahan diketahui dari hasil analisis tanah kandungan nitrogen pada tingkat yang rendah. Sehingga pada tanah yang tidak diberikan aplikasi pupuk nitrogen menjadikan tanah tersebut kekurangan unsur hara nitrogen. Menurut Ibrahim dan Kasno (2008) N adalah unsur hara yang dibutuhkan paling besar jumlahnya dalam pertumbuhan tanaman. Fungsi hara Nsangat penting terutama pada pembentukan senyawa-senyawa protein dalam tanaman.

Pada perlakuan air laut terlihat tidak berbeda nyata baik pada kontrol maupun pada tanaman yang diberikan perlakuan. Hal ini diduga pada pertanaman yang diberi perlakuan air laut diberikan pada dosis yang sangat sedikit dan encer akibatnya garam- garam yang terkandung pada air laut tidak memberikan 
pengaruh yang nyata pada tanaman di penelitian.

Hasil analisis ragam menunjukkan tidak terjadi interaksi antara dosis pupuk NPK dan konsentrasi air laut terhadap rata- rata jumlah cabang pada tanaman kacang tanah, pengaruh mandiri dosis pupuk NPK menunjukkan hasil yang berbeda nyata pada perlakuan $\mathrm{p}_{0}$ dibandingkan $\mathrm{p}_{1}, \mathrm{p}_{2}$, dan $\mathrm{p}_{3}$, tetapi perlakuan $\mathrm{p}_{1}$ tidak berbeda nyata dengan perlakuan $\mathrm{p}_{2}$ dan $\mathrm{p}_{3}$.

Hasil analisis ragam menunjukkan terjadi perbedaan antara kontrol dan pemberian pupuk NPK. Hal ini diduga terjadi akibat kandungan pupuk NPK dapat melengkapi kekurangan unsur hara yang diperlukan tanaman pada saat tumbuh. Pada hasil analisis tanah diketahui terdapat unsur nitrogen yang sedikit yang terkandung pada tanah campuran yang digunakan pada penelitian.

Tabel 3. Rata-rata Jumlah Cabang (batang)

\begin{tabular}{lrrr} 
Jumlah Cabang (batang) & Umur 30 HST & Umur 45 HST & Umur 60 HST \\
\hline Dosis NPK & & & \\
$\mathrm{p}_{0}$ & $8,88 \mathrm{a}$ & $10,46 \mathrm{a}$ & $14,13 \mathrm{a}$ \\
$\mathrm{p}_{1}$ & $11,85 \mathrm{~b}$ & $20,68 \mathrm{~b}$ & $22,23 \mathrm{~b}$ \\
$\mathrm{p}_{2}$ & $12,28 \mathrm{~b}$ & $20,93 \mathrm{~b}$ & $27,01 \mathrm{~b}$ \\
$\mathrm{p}_{3}$ & $12,78 \mathrm{~b}$ & $24,51 \mathrm{~b}$ & $29,26 \mathrm{~b}$
\end{tabular}

\section{Konsentrasi Air Laut}

$\begin{array}{llll}\mathrm{a}_{0} & 11,26 \mathrm{a} & 17,20 \mathrm{a} & 21,73 \mathrm{a} \\ \mathrm{a}_{1} & 11,69 \mathrm{a} & 19,26 \mathrm{a} & 22,89 \mathrm{a} \\ \mathrm{a}_{2} & 12,46 \mathrm{a} & 19,28 \mathrm{a} & 23,36 \mathrm{a} \\ \mathrm{a}_{3} & 10,35 \mathrm{a} & 20,84 \mathrm{a} & 24,65 \mathrm{a}\end{array}$

Keterangan : Angka rata-rata pada setiap kolom yang ditandai dengan huruf yang sama menunjukkan tidak berbeda nyata menurut Uji Jarak Berganda Duncan pada taraf 5\%.

Menurut Hardjowigeno (2010) Nitrogen pada tanaman berperan dalam pertumbuhan vegetatif tanaman. Nitrogen menjadi bahan penyusun protein pada tubuh tanaman. Hasil analisis tanaman pada perlakuan air laut menunjukkan tidak berbeda nyata hal ini sejalan dengan tinggi tanaman, dan luas daun. Diduga akibat terlalu sedikitnya konsentrasi air laut yang diberikan mengakibatkan pengaruh dari kandungan garam-garam yang terkandung pada air laut tidak terlihat. Diketahui kandungan garam pada air laut $\pm 3,5 \%$ dan pada saat penelitian diencerkan kembali menggunakan air tawar.

Hasil analisis ragam menunjukkan tidak terjadi interaksi antara dosis pupuk 
NPK dan konsentrasi air laut terhadap rata- rata jumlah polong per tanaman pada tanaman kacang tanah. Pengaruh mandiri dosis pupuk NPK menunjukkan hasil yang berbeda nyata pada perlakuan $\mathrm{p}_{0}$ dibandingkan $\mathrm{p}_{1}, \mathrm{p}_{2}$, dan $\mathrm{p}_{3}$, tetapi perlakuan p1 tidak berbeda nyata dengan perlakuan $\mathrm{p}_{2}$ dan $\mathrm{p}_{3}$. Rata- rata jumlah polong per tanaman dapat dilihat dalam Tabel 4.

Hasil analisis ragam menunjukan berbeda nyata antara taraf perlakuan kontrol dan perlakuan NPK. Hal ini sejalan dengan tinggi tanaman, luas daun, dan jumlah cabang. Diduga pemberian pupuk NPK dapat memberikan kecukupan unsur hara pada tanaman kacang tanah. Salah satu unsur yang berperan dalam perkembangan generatif dan akar adalah pupuk K. Walaupun pada hasil analisis tanah kandungan $\mathrm{K}$ pada kondisi sedang, namun diduga tanaman kacang tanah masih membutuhkan tambahan unsur hara bagi perkembangan polong tanaman. Sehingga pemberian NPK mampu meningkatkan hasil dari kacang tanah pada saat penelitian.

Unsur K b sebagai pembentuan pati, mengaktifkan enzim, pembukaan stomata dalam hal ini kalium berperan dalam mengatur pernapasan dan penguapan, kalium juga berperan dalam proses fisiologi dalam tanaman, proses metabolic dalam sel mempengaruhi penyerapan unsur-unsur lain, mempertinggi daya tahan terhadap kekeringan dan penyakit, juga berperandalam perkembangan akar (Hardjowigeno, 2010).

Tabel 4. Rata-rata Jumlah Polong per Tanaman (buah)

\begin{tabular}{|c|c|}
\hline Perlakuan & Jumlah Polong per Tanaman (buah) \\
\hline \multicolumn{2}{|l|}{ Dosis NPK $(\mathrm{P})$} \\
\hline $\mathrm{p}_{0}(0$ gr/polybag $)$ & $12,99 \mathrm{a}$ \\
\hline $\mathrm{p}_{1}(1,2 \mathrm{gr} /$ polybag $)$ & $16,56 \mathrm{~b}$ \\
\hline $\mathrm{p}_{2}(1,8 \mathrm{gr} / \mathrm{polybag})$ & $17,60 \mathrm{~b}$ \\
\hline $\mathrm{p}_{3}(2,4 \mathrm{gr} /$ polybag $)$ & $18,38 \mathrm{~b}$ \\
\hline \multicolumn{2}{|l|}{ Konsentrasi Air Laut (A) } \\
\hline $\mathrm{a}_{0}(0 \mathrm{ml} / \mathrm{L} /$ polybag $)$ & $16,33 \mathrm{a}$ \\
\hline $\mathrm{a}_{1}(30 \mathrm{ml} / \mathrm{L} /$ polybag $)$ & $14,85 \mathrm{a}$ \\
\hline $\mathrm{a}_{2}(40 \mathrm{ml} / \mathrm{L} /$ polybag $)$ & $17,36 \mathrm{a}$ \\
\hline $\mathrm{a}_{3}(50 \mathrm{ml} / \mathrm{L} /$ polybag $)$ & $16,99 \mathrm{a}$ \\
\hline
\end{tabular}


Pada perlakuan tanaman menggunakan air laut terlihat tidak berbeda nyata. Hal ini diduga akibat pemberian air laut yang terlampau sedikit sehingga tidak terlihat pada tanaman kacang tanah. Selain itu unsur garam yang terdapat pada air laut salah satunya Na yang mampu menggantikan fungsi pupuk kalium. Namun karena kandungan kalium berada pada kondisi ada (sedang) dan air laut yang terlalu sedikit sehingga idak terlihat pengaruhnya.

Hasil analisis ragam menunjukkan tidak terjadi interaksi antara dosis pupuk NPK dan konsentrasi air laut terhadap rata- rata bobot polong basah per tanaman pada tanaman kacang tanah, pengaruh mandiri dosis pupuk NPK menunjukkan hasil yang berbeda nyata pada perlakuan $\mathrm{p}_{0}$ dibandingkan $\mathrm{p}_{1}, \mathrm{p}_{2}$, dan $\mathrm{p}_{3}$, tetapi perlakuan $\mathrm{p}_{1}$ tidak berbeda nyata dengan perlakuan $\mathrm{p}_{2}$ dan $\mathrm{p}_{3}$.

Hasil analisis ragam menunjukkan berbeda nyata antara taraf perlakuan kontrol dan perlakuan NPK. Hal ini sejalan dengan hasil analisis jumlah polong pertanaman. Kandungan kalium yang mampu meningkatkan pertumbuhan buah pada tanaman yang diberi perlakuan NPK meningkat sehingga membantu pertumbuhan bobot polong basah pertanaman. Menurut Wahyudin dkk., (2015), nitrogen adalah salah satu unsur hara makro esensial bagi tanaman yang diperlukan dalam pembentukan dan pertumbuhan vegetatif tanaman serta sebagai bahan dasar penyusunan protein dan pembentukan klorofil, sehingga dapat meningkatkan bobot basah polong.

Tabel 5. Rata-rata Bobot Polong Basah per Tanaman (g)

\begin{tabular}{lc} 
Perlakuan & 3obot Polong Basah per Tanaman $(\mathrm{g})$ \\
\hline Dosis NPK $(\mathrm{P})$ & \\
$\mathrm{p}_{0}(0 \mathrm{gr} /$ polybag $)$ & $19,38 \mathrm{a}$ \\
$\mathrm{p}_{1}(1,2 \mathrm{gr} /$ polybag $)$ & $23,92 \mathrm{~b}$ \\
$\mathrm{p}_{2}(1,8 \mathrm{gr} /$ polybag $)$ & $24,96 \mathrm{~b}$ \\
$\mathrm{p}_{3}(2,4 \mathrm{gr} /$ polybag $)$ & $24,37 \mathrm{~b}$
\end{tabular}

Konsentrasi Air Laut (A)

$\begin{array}{ll}\mathrm{a}_{0}(0 \mathrm{ml} / \mathrm{L} / \text { polybag }) & 21,30 \mathrm{a} \\ \mathrm{a}_{1}(30 \mathrm{ml} / \mathrm{L} / \text { polybag }) & 22,45 \mathrm{a} \\ \mathrm{a}_{2}(40 \mathrm{ml} / \mathrm{L} / \text { polybag }) & 24,42 \mathrm{a} \\ \mathrm{a}_{3}(50 \mathrm{ml} / \mathrm{L} / \text { polybag }) & 24,46 \mathrm{a}\end{array}$

Keterangan : Angka rata-rata pada setiap kolom yang ditandai dengan huruf yang sama menunjukkan tidak berbeda nyata menurut Uji Jarak Berganda Duncan pada taraf $5 \%$. 
Hasil analisis ragam menunjukkan tidak terjadi perbedaan yang berbeda nyata antara perlakuan kontrol dan perlakuan menggunakan air laut pada berbagai taraf. Hal ini sejalan dengan hasil analisis ragam tinggi tanaman, luas daun, jumlah cabang, jumlah polong, maupun berat polong diduga pemberian taraf perlakuan air laut yang diencerkan kembali dan kandungan garam yang hanya 3,5\% sangat sedikit sehingga tidak memberikan efek yang berbeda nyata pada tanaman kacang tanah.

Hasil analisis ragam menunjukkan tidak terjadi interaksi antara dosis pupuk NPK dan konsentrasi air laut terhadap rata- rata hasil polong basah per plot pada tanaman kacang tanah, pengaruh mandiri dosis pupuk NPK menunjukkan hasil yang berbeda nyata pada perlakuan $\mathrm{p}_{0}$ dibandingkan $\mathrm{p}_{1}, \mathrm{p}_{2}$, dan $\mathrm{p}_{3}$, tetapi perlakuan $\mathrm{p}_{1}$ tidak berbeda nyata dengan perlakuan $\mathrm{p}_{2}$ dan $\mathrm{p}_{3}$. Rata-rata hasil polong basah per plot dapat dilihat dalam Tabel 6.

Tabel 6. Rata-rata Hasil Polong Basah per Plot (g)

\begin{tabular}{lc}
\hline Perlakuan & Hasil Polong Basah per Plot $(\mathrm{g})$ \\
\hline Dosis NPK (P) & \\
$\mathrm{p}_{0}(0 \mathrm{gr} /$ polybag $)$ & $180,61 \mathrm{a}$ \\
$\mathrm{p}_{1}(1,2 \mathrm{gr} /$ polybag $)$ & $218,18 \mathrm{~b}$ \\
$\mathrm{p}_{2}(1,8 \mathrm{gr} /$ polybag) & $223,62 \mathrm{~b}$ \\
$\mathrm{p}_{3}(2,4 \mathrm{gr} /$ polybag) & $231,31 \mathrm{~b}$ \\
Konsentrasi Air Laut $(\mathrm{A})$ & \\
$\mathrm{a}_{0}(0 \mathrm{ml} / \mathrm{L} /$ polybag) & $212,93 \mathrm{a}$ \\
$\mathrm{a}_{1}(30 \mathrm{ml} / \mathrm{L} /$ polybag $)$ & $209,03 \mathrm{a}$ \\
$\mathrm{a}_{2}(40 \mathrm{ml} / \mathrm{L} /$ polybag $)$ & $222,28 \mathrm{a}$ \\
$\mathrm{a}_{3}(50 \mathrm{ml} / \mathrm{L} /$ polybag $)$ & $209,47 \mathrm{a}$
\end{tabular}

Keterangan : Angka rata-rata pada setiap kolom yang ditandai dengan huruf yang sama menunjukkan tidak berbeda nyata menurut Uji Jarak Berganda Duncan pada taraf 5\%.

Hasil analisis ragam menunjukkan pada pemberian NPK memberikan pengaruh yang berbeda nyata dibanding kontrol. Hal ini diduga pemberian NPK mampu meningkatkan hasil pada tanaman kacang tanah. Hal ini sejalan dengan hasil analisis ragam pada berat polong pertanaman yang menunjukkan pemberian pupuk NPK meningkatkan bobot polong pertanaman kacang tanah. Pada saat penelitian serangan hama penyakitpun ditemui tetapi dalam intensitas yang tidak terlalu besar sehingga gangguan kehilangan hasil dari hasil pertanaman tidak turun 
terlalu jauh pada hasil analisis rata-rata hasil polong basah per plot.Pupuk NPK memiliki unsur hara yang seimbang, dalam pupuk NPK terdapat unsur N, P, dan K (Rauf dkk., 2000).

Unsur hara yang berperan penting dalam pembentukan biji yaitu unsur hara P dan Ca yang diperoleh dari perlakuan pupuk NPK. Damanik dkk., (2010) menambahkan bahwa di dalam tubuh tanaman fosfor memberikan peranan yang penting dalam pembentukan bunga, buah, dan biji. Tersedianya $\mathrm{Ca}$ dan unsur lainnya menyebabkan pertumbuhan generatif menjadi lebih baik, sehingga pengisian polong lebih sempurna dan mengakibatkan hasil menjadi lebih maksimal (Sutarto et al., 1985).

Hasil analisis ragam perlakuan konsentrasi air laut menunjukkan tidak ada pengaruh nyata antara perlakuan. Hal ini diduga pemberian air laut pada penelitian terlampau sedikit. Pada air laut kandungan garam terlarut hanya sebesar 3,5\% dan pada penelitian diencerkan kembali menggunakan air tawar sehingga diduga garam yang diserap sangat sedikit dan tidak terlihat pada tanaman baik pertumbuhan vegetatif maupun generatif. Hal ini sejalan dengan hasil analisis ragam tinggi tanaman, luas daun, jumlah cabang, jumlah polong, dan bobot polong pertanaman.

\section{KESIMPULAN}

Berdasarkan hasil penelitian mengenai pertumbuhan dan hasil kacang tanah yang diberi berbagai dosis NPK dan konsentrasi air laut dapat disimpulkan tidak terjadi interaksi antara berbagai dosis NPK dan konsentrasi air laut terhadap pertumbuhan dan hasil kacang tanah.

Secara mandiri dosis NPK 1,2 g/polybag suda mampu menunjukkan pengaruh terbaik terhadap semua parameter pengamatan pada pertumbuhan tanaman kacang tanah, sedangkan berbagai konsentrasi air laut tidak menunjukkan hasil yang berbeda nyata pada semua parameter pengamatan.

\section{DAFTAR PUSTAKA}

Badan Pusat Statistik. 2019. Produksi Kacang Tanah Nasional. <http://www.bps.go .id>. Diakses Februari 2019. 
Brown J, Colling A, Park D, Phillips J, Rothery D, Wright J. 1989. Ocean Chemistry and Deep Sea Sediments. Open University.

Damanik, M. Madjid B., Bachtiar Effendi Hasibuan, Fauzi, Sarifuddin, Hamidah Hanum. 2010.

Pemupukan Tanah. USU Press. Medan.

Fitter A.H. dan Hay, R.K.M. 1991. Fisiologi Lingkungan Tanaman. Universitas Gajah Mada, Yokyakarta.

Gomez, K.A. dan A.A. Gomez. 2007. Prosedur Statistik untuk Penelitian Pertanian. UI-Press. Jakarta.

Hardjowigeno, S. 2010. Ilmu Tanah. Akademika Pressindo. Jakarta.

Ibrahim, A.S dan A. Kasno . 2008. Interaksi pemberian kapur pada pemupukan urea Terhadap kadar $N$ tanah dan serapan $N$ tanaman Jagung (Zea mays. L). Balai Penelitian Tanaman Pangan. Semarang.

Pickard, G.L. danW.J. Emery. 1990. Descriptive Physical Oceanography:An Introduction. Pergamon Press, Oxford.

Rauf, A. W., T. Syamsuddin, dan R. S. Sri. 2000. Peranan Pupuk NPK pada Tanaman Padi. Departemen Pertanian. Badan Penelitian dan Pengembangan Pertanian. Loka Pengkajian Teknologi Pertanian Koya Barat, Irian Jaya

Sarwono H. 1995. Ilmu tanah. Akademika Pressindo. Jakarta.

Sutarto, V, S. Hutaami, dan B. Soeherdy. 1985. Pengapuran dan Pemupukan Molibdenum, Magnesium, dan Sulfur pada Kacang Tanah. Dalam seminar hasil penelitian tanaman pangan volume 1 palawija. Badan Penelitian dan Pengembangan Pertanian. Pusat Penelitian dan Pengembangan Tanaman Pangan Bogor. 227 : 146-155.

Wahyudin, A., Rumita, Bachtiar, D.C. 2015. Pengaruh Jarak Tanam Berbeda Pada Berbagai Dosis Pupuk Organik Pertumbuhan Jagung Hibrida P12 Jatinangor. Jurnal Kultivasi 14(1):1-8. 